\title{
Sebezkušenostní skupiny pro studenty učitelství v online prostředí
}

\author{
Petra Hořejšová ${ }^{a}$, Zuzana Štefánková ${ }^{b}$ \\ a Jihočeská univerzita, Pedagogická fakulta, Katedra psychologie \\ ${ }^{\mathrm{b}}$ Jihočeská univerzita, Pedagogická fakulta, Katedra speciální pedagogiky
}

Distanční výuka, a vůbec práce se skupinou v online prostředí, má svá specifika, kterými se velmi odlišuje od běžného způsobu práce se skupinou v reálném prostředí. Řada profesionálů - pedagogů, poradců, terapeutů apod. kteří modifikovali svůj styl práce na dočasný „online modus“, se domnívá, že využití online prostředí pro práci s lidmi se nedá označit jako horší nebo lepší, ale nejlépe výstižná charakteristika je jiné. Právě proto vyžaduje kreativní hledání vhodných způsobů a možností realizace výuky, aby bylo dosaženo vytyčených cílů. K tomuto tématu už bylo během pandemie nemoci covid-19 napsáno poměrně dost, zejména $\mathrm{z}$ řad pedagogư${ }^{1}$, kteří byli na jaře 2020 nečekaně ze dne na den odkázáni na online prostředí. Museli se tak rychle na toto prostředí adaptovat a hledat způsoby, jak v něm s žáky a studenty efektivně pracovat. Výzkumně se tématu praxe distanční výuky a jejím souvislostem věnovali např. Rokos a Vančura (2020) nebo Duschinská a High (2020).

V době opětovného uzavření škol na podzim 2020 začaly být dopady distanční výuky na žáky různého věku v médiích a na veřejnosti často diskutovaným tématem (Česká televize, 2020). ${ }^{2}$ Mimo jiné odborníci upozorňovali na skutečnost, že přes slibně se vyvíjející možnosti funkční online výuky a komunikace mezi učitelem a žáky zůstává opomíjená zejména oblast vztahů ve třídě a vztahu pedagoga k žákům. Problematickou se podle nich ukázala situace zvláště tehdy, když se z výhledu krátkodobé distanční výuky stala dlouhodobá, a žáci se tak nemohli delší dobu osobně setkávat. Další riziko představují

1 Na neočekávanou situaci a uzavření škol na jaře 2020 rychle reagovali pedagogové ve formě různých rad, návodů a inspirací pro výuku v online prostředí, např. na webu Metodický portál RVP.cz. Pokud zadáme do vyhledávání „online výuka“, nalezneme všechny příspěvky na toto téma: https://rvp.cz/vyhledavani?q=online+v\%C3\%BDuka\&sb=Vyhledat

2 Do pořadu Fokus Václava Moravce, který měl téma Povolání učitel(-ka), přijali pozvání ministr školství R. Plaga, děkan Pedagogické fakulty UK M. Nedělka, ekonom J. Libich, učitelky B. Slámová a P. Mazancová, učitel T. Chrobák, profesor kybernetiky M. Šebek nebo ředitelka gymnázia M. Fibigerová, někteří mimo jiné diskutovali také o dopadech distanční výuky na vztahy mezi žáky a zároveň na vztah mezi učitelem a žáky. Dostupné z https:// www.ceskatelevize.cz/ivysilani/11054978064-fokus-vaclava-moravce/220411030530007 
nově vznikající třídy: především u žáků, kteří přecházejí na druhý stupeň nebo nastupují na střední školu. Kromě zajištění potřebných základů vzdělání se v těchto situacích jako důležitá jeví podpora navázání a udržení vztahů s žáky ve skupině. Neméně důležité je, aby učitel udržel kontakt s každým žákem a věděl, co se s ním během distanční výuky děje. Náměty, jak pracovat na klimatu školní třídy, přináší např. Bartošová (2020) a Kročáková (2021).

A právě z tohoto úhlu pohledu jsme se společně se studenty učitelství zaměřili na obsahy seminářů během distanční výuky. Výuka námi představovaného prakticky orientovaného předmětu probíhala na podzim 2020, proto jsme měli možnost již $\mathrm{v}$ předstihu o možnostech funkční distanční výuky přemýšlet a plánovat ji. Vzhledem $\mathrm{k}$ tomu, že obsahem předmětu je práce ve skupině se zaměřením na vzájemné vztahy, skupinovou dynamiku, sebezkušenost studentů a skrze vlastní prožitky i získání nových dovedností pro práci se skupinou, distanční forma pro nás byla velkou výzvou. Kladli jsme si otázku, zda je práce se skupinou v této podobě v online prostředí vůbec možná. $V$ níže předkládaném textu bychom chtěli sdílet zkušenosti z naší praxe a na reflexích studentů ukázat, jak lze online prostředí využít.

\section{Charakteristika předmětu „zdravá škola“}

Seminář „zdravá škola“ je povinně volitelný předmět pro studenty magisterského studia učitelství na Pedagogické fakultě Jihočeské univerzity v Českých Budějovicích. Název předmětu souvisí s pěstováním zdravých vztahů v rámci třídy a školy a v našem pojetí se vztahuje také k osvojování „know-how“ pro podporu psychického zdraví žáků prostřednictvím vztahů. Za běžné vysokoškolské výuky probíhá formou skupinové práce se studenty se zaměřením na sebezkušenost a získávání znalostí, dovedností a technik pro práci se skupinou. K pravidelnému setkávání dochází jednou týdně na dvě vyučovací hodiny. Vzhledem $\mathrm{k}$ tomu, že se pandemická situace $\mathrm{v}$ naší republice $\mathrm{z}$ důvodu nemoci covid-19 již před zahájením výuky v akademickém roce 2020/2021 zhoršovala a existovaly obavy, že zimní semestr proběhne opět v distanční podobě, rozhodli jsme se předmět připravit na obě možné podoby výuky i př́ípadné stř́íání běžné výuky s online formou. 79 studentů, kteří se předmětu zúčastnili, bylo rozděleno na čtyři seminární skupiny (dvě o 20 studentech, jedna o 13 studentech a jedna o 26 studentech). Jedna vyučující vedla tři seminární skupiny a druhá vyučující vedla jednu seminární skupinu. 
Se dvěma skupinami se nám podařilo setkat se dvakrát ve venkovním prostředí školy ještě na počátku semestru, $\mathrm{s}$ dalšími dvěma skupinami proběhlo v této formě pouze jedno setkání. Protože se jednalo o nově vznikající skupiny studentů různých oborů, kteří se převážně neznali, byla tato možnost „setkání naživo" využita ke vzájemnému seznámení a přípravě na případný přesun výuky do online prostoru. $\mathrm{V}$ něm jsme následně strávili celý semestr a využili této situace $\mathrm{k}$ prozkoumání možností práce se skupinou v online prostoru. Ostatní semináře v zimním semestru 2020 byly realizovány online na platformě MS Teams.

Na prvním semináři si studenti pomocí myšlenkového experimentu představili, že úspěšně zakončili studium na vysoké škole a nastoupili do nového zaměstnání na střední školu, kde začínají v pozici třídního učitele / třídní učitelky a dostali skupinu žáků prvního ročníku, kteří se kvůli distanční výuce nemohli zúčastnit adaptačního kurzu, a nestihli se tak blíže seznámit. Seminář jsme vnímali jako výzvu vypořádat se s takovou situací, pokusit se navázat vztah s novými žáky a vytvořit společně s nimi tř́́dní kolektiv. Tato myšlenka se jevila jako ideální i z toho důvodu, že se studenti vzájemně téměř neznali. Studenti si tak během seminářů stř́ídavě vyzkoušeli jak roli tř́́dního učitele, který vedl aktivitu v semináři a průběh třídnické hodiny, tak roli žáka v nově vznikajícím kolektivu.

Kromě podílení se na skupinovém dění měl každý student za úkol vytvořit jednu aktivitu pro práci se skupinou žáků pro běžnou školní výuku a jednu aktivitu pro online prostředí. Témata byla předem vybraná a pro vytvoření požadované aktivity existoval námi vytvořený vzor tak, aby všechny odevzdané aktivity v závěru vytvořily jeden společný soubor - jakousi praktickou příručku. Tuto příručku mohou následně studenti - budoucí pedagogové - využít při práci se žáky v praxi. Součástí aktivity vytvořené studenty byl nejen popis cílů, př́nosů pro žáky a podrobný návod, jak aktivitu správně realizovat, ale také úvaha o možných úskalích a rizicích, o využitelnosti aktivity, příp. jejích modifikacích ve skupině se žákem se speciálními vzdělávacími potřebami (např. žák s tělesným postižením). Inspiraci pro tyto aktivity mohli studenti čerpat ze všech aktuálně dostupných zdrojů (knih, internetu), popř. mohli využít vlastní fantazii i zkušenosti z volnočasových aktivit. Témata pro vytváření aktivit byla následovná: hry na seznámení, hry na rozvoj spolupráce, hry na rozvoj komunikačních dovedností, hry na rozvoj důvěry, hry na rozvoj motivace, hry na rozvoj hodnotové orientace, empatie, hry pro uvolnění a relaxaci, hry na prevenci sociálně patologických jevů, hry na rozvoj sebepoznání a hry na ven. 


\section{Popis průběhu seminářů}

Jako komunikační platformu jsme využili online videokonferenci v MS Teams. Protože vzniklé skupiny studentů z různých oborů měly rozdílné zkušenosti s online prostředím, přirozeným prvním krokem bylo společné zorientování se, což nám zabralo zhruba jedno setkání. V dalším jsme společně objevovali další možnosti online prostředí, které bychom mohli pro naše potřeby využít. Také jsme pro podmínky online prostoru jemně upravili jednoduchá pravidla pro fungování ve skupině, která byla nastavena na začátku semestru ještě „V běžné formě výuky“.

Tato minimální pravidla vnímáme, podobně jako v jiných sebezkušenostních formách práce se studenty, jako nesmírně důležitá pro navázání vztahu, vytvoření bezpečného prostředí a přenesení alespoň trochy reálného světa do online interakcí (Kolařík, 2019).

Pravidla se týkala zejména těchto čtyř oblastí:

Čas. Podmínkou bylo včasné připojení a setrvání na celém bloku, což usnadňovalo práci v jednotlivých aktivitách a zároveň zajišt'ovalo onen pocit bezpečí a pohody celé skupině. Samozřejmě i my jsme se setkávali s technickými problémy při přetížení MS Teams a připojování ke skupině.

Organizace a prostor. Vzhledem k tomu, že jsme nemohli zajistit sezení v kruhu, které se využívá při práci se skupinou právě z toho důvodu, aby na sebe všichni účastníci mohli vidět, domluvili jsme se na tom, že během našeho setkávání budeme mít všichni zapnuté kamery. Protože kvalita připojení jednotlivých členů skupiny byla značně různorodá a možnosti jejich vybavení také, bylo možné nahradit obraz z kamery fotografií své tváře, abychom všichni viděli, s kým konkrétně mluvíme. Někteří studenti vyřešili chybějící kamery přidáním mobilu k počítači jako zástupné kamery. Právě toto pravidlo považujeme za velmi důležité, protože možnost vidět druhým do tváře nám umožňuje lépe odečítat jejich pocity, a vzájemně tak na sebe lépe reagovat. $\mathrm{V}$ rámci tohoto pravidla mohlo být opět (vzhledem $\mathrm{k}$ možnostem studentů) jen doporučeno, aby si na práci ve skupině zkusili zajistit klidné prostředí, kde je nikdo nebude vyrušovat.

Komunikace. Komunikační pravidla upozorňovala na to, že každý ve skupině má právo vyjádřit svůj názor, aniž by byl hodnocen jako dobrý či špatný. Dủležitou součástí komunikace byla podmínka, aby každý mluvil sám za sebe 
v jednotném čísle a oslovoval druhé jmény, která jsme si zvolili na začátku semináře.

Bezpečí. Bezpečí považujeme pro práci se skupinou jako nejdůležitější. Studenti byli seznámeni s možností využít pravidlo STOP, pokud by se nechtěli z nějakého důvodu aktivity zúčastnit. Součástí pravidla byla samozřejmě možnost ho použít bez udání důvodu, proč se pro něj student rozhodl, s tím, že pokud by se jej rozhodl vysvětlit, může to být obohacením pro skupinu, která tak může porozumět jeho volbě, a získat tím nové zkušenosti.

Jako optimální náhrada komunikace v kruhu se ukázalo po vyzkoušení více variant postupné předávání slova mezi členy skupiny (,... a slovo předávám [JMÉNO]..."). Tato možnost byla příjemnější než vyvolávání studentů vedoucí semináře, a vznikla tak příležitost, aby se studenti mohli oslovovat jménem mezi sebou navzájem, což také napomáhalo k odlehčení a navazování vzájemných vztahů. Součástí každého setkání bylo také „úvodní kolečko“, ve kterém jsme mimo pozdravu s ostatními sdíleli to, jak se dneska cítíme, popř. co se nám během uplynulého týdne podařilo nebo jak se nám $v$ distanční výuce vede. To samotné, ačkoliv zabralo určitý čas, pomohlo k navození atmosféry a společné aktivizaci pro další práci. Zároveň bylo díky tomu patrné, jakým způsobem jsou jednotlivci pro skupinovou práci naladění. Tato forma se zdála důležitá také proto, že jsme tyto informace nemohli získávat spontánně, pozorováním $\mathrm{z}$ reálného setkání ve třídě, a vzhledem $\mathrm{k}$ nestandardním a náročným podmínkám distanční výuky z důvodu uzavření škol se jednalo též o způsob, jak s druhými sdílet své pocity v této složité situaci.

Během prvního měsíce našeho setkávání jsme se zaměřili na vztahy mezi studenty uvnitř nově vznikajících skupin a zároveň naši činnost propojovali s teorií tak, aby studenti mohli získané znalosti uplatnit při jejich samostatném vytváření aktivit. Zabývali jsme se tedy nejen teorií práce se školní třídou, její charakteristikou a typy třídního kolektivu, ale i obecnými zákonitostmi skupinové dynamiky a podmínkami pro práci ve skupině, včetně vedení skupiny z pozice třídního učitele. Zamýšleli jsme se také nad úlohou třídnických hodin a možnostmi jejich využití v rámci školního roku (Braun et al., 2014; Soják, 2018). V následujících dvou měsících jsme se už věnovali aktivitám studentů; během jednoho semináře jsme vyzkoušeli maximálně dvě aktivity a následně realizovali reflexi a zpětnou vazbu od studentů v roli žáků. Tyto diskuze někdy otevíraly témata, která jsme mohli následně společně promýšlet. V rámci prováděných aktivit jsme do naší skupiny zahrnuli též imaginární 
postavu žáka s poruchou autistického spektra, kterého si na začátku aktivity někdo ze studentů vylosoval a pokusil se následně dát zpětnou vazbu i z pohledu tohoto žáka, což někdy přinášelo zajímavé postřehy. Pro lepší vcítění se do této pozice se studenti seznámili s jeho podrobnou charakteristikou a zálibami. Zároveň jsme si jeho postavu přiblížili i v rámci informačního bloku o dětech se speciálními vzdělávacími potřebami.

Náš společný pokus, ve kterém jsme zkoumali práci se skupinou a možnosti využití třídnických hodin v online prostoru, jsme ukončili v lednu roku 2021, kdy jsme se se studenty rozloučili a požádali je o anonymní reflexi k semináři.

\section{$3 \quad$ Reflexe studentů}

Reflexe studentů k představovanému semináři odrážejí zejména náhledy na přínosy semináře ve vztahu $\mathrm{k}$ jejich aktuální situaci vysokoškolských studentů v období dlouhodobého omezení sociálních vztahů. Na druhém místě bylo reflektování samotné organizace předmětu v online prostředí, které pro studenty představovalo novou zkušenost, kterou mohou využít v budoucí pedagogické praxi. Přestože reakce na organizaci a přínos semináře byly převážně kladné, v každé reflexi se zároveň objevovala potřeba vyjádřit se k online prostředí a distanční výuce jako takové - s povzdechem a přáním studentů, aby se vše vrátilo $\mathrm{k}$ předešlé prezenční výuce. Zároveň se ve většině reflexí objevovaly ve větší míře vlastní pocity studentů, které během seminářů prožívali; případně také popisovali, s jakými pocity předmět ukončili.

Tematicky jsme tyto komentáře rozdělili do čtyř kategorií:

\subsection{Reakce na př́nos semináře}

S1: Měl jsem možnost poznat vlastně úplně neznámé lidi. Navíc to byl seminář pro mě naprosto netypický, takový oddechový, za což jsem rád. Určitě to změnilo vůbec můj pohled na tř́dnické hodiny, které jsem měl zažité, že fungují pouze k vyřízení omluvenek. :)

S2: Ačkoliv jsem opravdu velký introvert, tak jsem zjistil, jak mi třeba prosté popovídání si se spolužáky cestou do menzy hrozně chybí a pár společných hodin přes teams to absolutně nenahradí. Také $\mathrm{z}$ toho důvodu jsem vděčný za tento seminář, protože jsem díky němu (alespoň přes obrazovku) mohl vidět i někoho jiného než rodiče nebo sourozence. 
S3: Co se týká online prostředí, tak díky těmto hodinám se nebudu muset obávat vedení vyučovacích hodin na vzdálenou výuku.

S4: Semináře mi přišly velmi užitečné obsahově. Také se mi líbila forma hodin, zapojili jsme se všichni a některé spolužáky jsem díky tomu poznala za jednu hodinu on-line.

\subsection{Organizace semináře}

S5: Z požadavku mít zapnuté kamery jsem z počátku byla nesvá, ale na konci jsem za to byla ráda. Je dobré vědět, ke komu mluvím, vytváří to ve mně větší pocit důvěry.

S6: Získala jsem inspiraci na mnoho her, které mohu s dětmi dělat. Seminář byl hezkým zahájením dne, př́ijemné probuzení. Vyhovovalo mi, že celý seminář byl veden nenásilně, přirozeně.

S7: Líbila se mi praktičnost semináře. Konečně něco, co se dá ve škole opravdu využít. Škoda, že jsme neměli takové předměty už od prváku.

S8: ... ani jsem nevěděla, kolik aktivit je možné dělat on-line. Bavilo mě to, zvlášt' snaha zařadit něco fyzického na rozdýchání, protažení, procházku.

S9: Na začátku mi vadilo, že jsme se, bohužel, museli přesunout do online prostředí, což nešlo ovlivnit. Ale poté jsem si říkala, že je to vlastně dobře v tom, že jsme si zkusili aktivity i v online prostředí, protože jindy bychom si to zkusit nemohli. Hry a aktivity ve tř́ídě by byly samozřejmě také fajn, ale určitě každý už někdy zažil, jak to funguje.

S10: Z pohledu budoucího učitele jsem si odnesla, že jde dělat skupinovou práci v online prostředí, ale myslím, že je důležité, aby opravdu všechny děti spolupracovaly a všechna technika běžela správně. :)

\subsection{Vztah $k$ online prostředí}

S11: Přijde mi, že učení v online podobě mě vyčerpává více než prezenční forma. Neustále být na počítači a psát něco. Proto mě hodiny zdravé školy odreagovaly a byla jsem ráda, že takto hodiny fungují.

S12: Ke konci už na mě dolehlo to, že všechny předměty na VŠ jsou on-line, cítila jsem se hodně unavená a cítila jsem i fyzickou bolest od neustálého sezení 
u počítače (bolest zad, pálení očí). Vyvolávalo to ve mě už nechut' se na on-line hodinách zapojovat a myslím, že by se to mohlo objevit i u dětí, pokud budou on-line výukou přetíženy.

S13: Závěrem bych dodala, že doufám $\mathrm{v}$ to, že vyučování bude do budoucna probíhat ve školní tř́dě / v reálném prostředí, kde dochází k přímému kontaktu žáků a učitelů mezi sebou, což je nezbytný prostředek pro socializaci dětí a pro jejich budoucnost.

\subsection{Pocity ze semináre}

S14: Byl to jeden z mála předmětů, na který jsem se upř́mně těšila.

S15: Z toho semináře jsem odcházela vždy pozitivně nabitá.

S16: Semináře pro mě ale byly fajn strávený čas, nikdo nebyl nijak pesimistický, a když náhodou měl někdo skleslou náladu, po semináři to bylo lepší. :)

S17: Tyto online hodiny byly vždy aktivní a po skončení vždy přišlo pozitivní naladění.

S18: Na hodiny jsem se těšila a nikdy jsem se nestresovala, což se stává málokdy.

\section{$4 \quad$ Zkušenosti z výuky}

Někteří studenti vnímají online prostředí jako prostor pro sdílení osobních informací pozitivněji než reálné prostředí, kde je pro ně otevření se skupině obtížnější. Platí to i obráceně, jsou studenti, kterým online prostředí nevyhovuje a potřebují sdílet tyto pocity v reálném prostředí. Pro někoho tedy online prostředí přináší větší důvěru a ztrátu ostychu, zatímco někomu jinému chybí reálnost, ztrácí pocity skupinové sounáležitosti a potřebu zapojit se do skupiny. Z hlediska velikosti skupiny se nám zdá ideální počet do 20 jedinců. Při větším počtu všechny aktivity trvají déle a je obtížnější poskytnout každému prostor k vyjádření. Jako užitečné se jeví klást důraz na řízení komunikace, které by mělo zůstat spolehlivým i přes technické problémy. Osvědčuje se postupné předávání slova navzájem mezi studenty, zapojení chatu, sledování mikrofonů studentů, kopírování některých instrukcí k aktivitám souběžně s vysvětlováním do chatu nebo využívání sluchátek, což redukuje šum. K přípravě semináře patří důkladné nachystání se na různé 
varianty realizace práce, které mohou nastat zejména $v$ důsledku nefunkčnosti některých funkcí aplikace $v$ MS Teams. Z toho důvodu je potřeba mít připravené záložní řešení, např. v podobě jiné aktivity, či využít jiné běžně dostupné aplikace pro online komunikaci. Technicky zvládnutý seminář lze připodobnit k př́ijemnému nerušenému prostředí pro skupinovou práci.

Přes uvedené možnosti řada studentů reflektovala prožívání limitů v rámci online realizovaných aktivit. Limity jsou vázané hlavně na nekomfortnost plynoucí z přetížení z dlouhodobé online výuky a omezené prožívání interakce v důsledku chybějících vjemů, jako jsou prostorové vnímání, spontánní evidování neverbálních projevů druhých, spontánní komunikace v rámci skupiny apod. S tím je spojena jinakost a nižší intenzita prožívání interakcí.

\section{Závěr}

Na základě našich zkušeností ze seminářů a reflexí od studentů jsme dospěli $\mathrm{k}$ přesvědčení, že práce se skupinou $\mathrm{v}$ online prostředí má sice svá určitá omezení, ale vzhledem k obtížné době, ve které se studenti nacházejí, má smysl se této činnosti věnovat. Studenti přišli kvůli dlouhodobému uzavření škol a dalším společenským opatřením o mnoho možností realizace a zdrojů podpory. Možnost pravidelného „online setkávání“ ve stabilní skupině se jeví jako účinná podpora a zdroj motivace na přechodnou dobu.

Z dlouhodobého hlediska vnímáme jako vhodné rozšíření nabídky předmětů zaměřených na sebezkušenost v pregraduální přípravě budoucích učitelů. Jako efektivnější se jeví např. podle zkušeností kolegů z Pedagogické fakulty Masarykovy univerzity v Brně (Soják, 2018) tř́semestrální varianta:

První semestr je zaměřen na sebepoznání, zlepšení sebepojetí a schopnosti sebereflexe, rozvoj sebezkušenosti. Druhý semestr je věnován rozvoji sociální a emoční inteligence, optimalizaci sociálních dovedností v oblasti interakce, zejména v komunikaci a kooperaci aj. Hlavním cílem ve třetím semestru je nácvik vedení skupiny pod př́mou supervizí lektorů a v intervizním konceptu účastníků.

Naše zkušenosti ze zimního semestru 2020 ale především potvrzují důležitost jak individuální, tak skupinové podpory studentů učitelství v průběhu studia, a to zejména v náročnějších obdobích, jako je začátek studia, konec studia a období distanční výuky. 


\section{Literatura}

Bartošová, K. (Ed.) (2020). Jak na online třídnické hodiny: praktická př́ručka pro školní psychology. Školský Psychológ / Školní Psycholog, 21(1-2), 1-42.

Braun, R., Marková, D., \& Nováčková, J. (2014). Praktikum školní psychologie. Portál.

Česká televize. (2020). Linka bezpečí řeší v nouzovém stavu častěji psychické obtíže dětí. Její provoz pritom komplikují opatření. https://ct24.ceskatelevize.cz/domaci/3220666-linka-bezpeciresi-v-nouzovem-stavu-casteji-psychicke-obtize-deti-jeji-provoz-pritom?fbclid=IwAR3rfcTUb_2IG0V2R_tI844SGLgGviqtoN38jOW4b1-21wAHOF3TJJBlfo

Duschinská, K., \& High, R. (2020). Reflexe nouzové výuky: distanční přednášky předmětu základy didaktiky. Pedagogická orientace, 30(2), 266-281.

Kolařík, M. (2019). Interakční psychologický výcvik. Grada.

Kročáková, Z. (2021, 31. března). Jak rozvíjet vztahy se žáky v době online výuky. htps://www. ucitelnazivo.cz/blog/jak-rozvijet-vztahy-se-zaky-v-dobe-online-vyuky.

Rokos, L., \& Vančura, M. (2020). Distanční výuka při opatřeních spojených s koronavirovou pandemií - pohled očima učitelů, žáků a jejich rodičů. Pedagogická orientace, 30(2), 122-155.

Soják, P. (2018). Osobnostně sociální rozvoj aneb strom, mozaika a vzducholod'. Grada.

\section{Autorky}

Mgr. et Mgr. Petra Hořejšová, Jihočeská univerzita, Pedagogická fakulta, Katedra psychologie, Dukelská 9, 37115, České Budějovice, e-mail: horejp01@pf.jcu.cz

Mgr. Zuzana Štefánková, Ph.D., Jihočeská univerzita, Pedagogická fakulta, Katedra speciální pedagogiky, Dukelská 9, 37115, České Budějovice, e-mail: stef@pf.jcu.cz 